\title{
The Civil and Criminal Methodologies of the Fourth Amendment
}

The Fourth Amendment ${ }^{1}$ controls both criminal and civil law enforcement activities, yet the courts have created distinctive methodologies ${ }^{2}$ for deciding cases within each area. They have applied a stricter, more ruleoriented "probable cause" analysis ${ }^{3}$ in criminal cases, but have resorted to a more flexible and less rule-bound "balancing" methodology in civil cases. Several recent Supreme Court decisions, ${ }^{4}$ however, have begun to close this gap between civil and criminal cases by making balancing unexceptional in criminal cases. The Supreme Court has begun to reshape the Fourth Amendment's criminal methodology in the image of the civil.

This Note argues that this recent expansion of the balancing approach is regrettable. Admittedly, it was time for a change in the role of the balancing methodology. We cannot cabin balancing within the civil cases if we take seriously the current explanations of when balancing should take place. But in adjusting the role of balancing, the Court should have restricted its use rather than expanded it. In all but a few types of cases, the traditional methodology of the criminal area offers a more workable and appropriate protection of the personal privacy interests secured by the Fourth Amendment than does balancing.

1. The Fourth Amendment provides:

The right of the people to be secure in their persons, houses, papers, and effects, against unreasonable searches and seizures, shall not be violated, and no Warrants shall issue, but upon probable cause, supported by Oath or affirmation, and particularly describing the place

to be searched, and the persons or things to be seized.

U.S. CoNST. amend. IV. The text makes no distinction between civil and criminal searches and seizures.

2. The "methodologies" discussed in this Note can be defined as the procedures used to formulate Fourth Amendment issues rather than the substantive factors used to determine the outcomes. This Note's analysis begins with the commonplace idea that procedures have their own substantive implications.

3. Probable cause to search is that level of information which would allow a man of reasonable caution to believe that the thing to be searched for or seized will be found in a designated location. Probable cause is usually defined with regard to arrest warrants. See Brinegar v. United States, 338 U.S. 160, 175-76 (1949). The definition changes only slightly for searches, forusing on location rather than likelihood of guilt. See Zurcher v. Stanford Daily, 436 U.S. 547, 558 (1978). This standard governs most criminal cases, except for stop-and-frisk situations. See Terry v. Ohio, 392 U.S. 1 (1968) (officer may search suspect for weapons absent probable cause in order to protect himself).

As used in this Note, "probable cause methodology" encompasses the warrant requirement. Before making a search or seizure, investigators must satisfy a magistrate that probable cause actually exists. Most types of probable cause searches or seizures must be warranted. Arkansas v. Sanders, 442 U.S. 753, 757-60 (1979).

4. Ser, e.g., Michigan v. Long, 103 S. Ct. 3469 (1983) (protective search of individual extends to search of his car); United States v. Place, 103 S. Ct. 2637 (1983) (warrantless seizure of luggage and passenger in airport); Florida v. Royer, 103 S. Ct. 1319 (1983) (plurality opinion) (investigative detention of suspect in airport). 


\section{Development of the Two Methodologies}

The balancing and probable cause methodologies have been employed as distinct ways of defining unreasonable searches and seizures. Quite by chance, the boundary between civil and criminal cases has formed the dividing line between the two methodologies. Only recently has the pattern begun to change.

\section{A. The Customary Usages}

Courts have long used the warrant requirement and the probable cause standard to evaluate criminal searches and seizures. ${ }^{5}$ Under this test, reasonable searches and seizures can take place only after law enforcement officers establish the rather stable set of facts ${ }^{6}$ that make up probable cause. ${ }^{7}$ Most categories of cases $^{8}$ also require the officers to obtain a search or arrest warrant from a judicial officer before acting. ${ }^{\theta}$ While the historical relation between reasonable searches and warranted searches remains unclear, ${ }^{10}$ courts now describe unwarranted criminal searches or

5. The probable cause and warrant requirements were responsible for the outcomes in some of the earliest Fourth Amendment cases. See, e.g., Agnello v. United States, 269 U.S. 20 (1925) (warrant required even though articles reasonably believed to be inside house); Ex parte Jackson, 96 U.S. 727 (1877) (warrant necessary to open and inspect mail). That is not to say that the probable cause methodology had never been challenged before the emergence of the balancing approach. In United States v. Rabinowitz, 339 U.S. 56, 63-64 (1950), and Harris v. United States, 331 U.S. 145, 150 (1947), the Court adopted a "facts and circumstances" approach which left to the trier of fact the issue of whether a search or seizure was reasonable. Justice Frankfurter, in dissent, argued that the history of the amendment made the warrant requirement a prerequisite to reasonableness. Rabinowitz, 339 U.S. at 70; Harris, 331 U.S. at 161-62. Frankfurter's rather absolutist view later became law as the Court strengthened the warrant requirement in Chimel v. California, 395 U.S. 752 (1969) (warranted searches the norm, warrantless search of arrestee must be confined to area in his or her control). The current struggle between balancing and probable cause, because it pits broad rules against a more case-oriented methodology, recapitulates this earlier dispute.

6. In asking whether probable cause exists, courts have considered a restricted set of variables. See infra p. 1128.

7. See Texas v. White, 423 U.S. 67 (1975) (per curiam) (warrantless car search reasonable because based on probable cause).

8. Exceptions to the warrant requirement include automobile searches, Chambers v. Maroney, 399 U.S. 42, 51 (1970), consent searches, Schneckloth v. Bustamonte, 412 U.S. 218, 222 (1973), administrative searches, Colonnade Catering Corp. v. United States, 397 U.S. 72, 76 (1970), searches under exigent circumstances which make procuring a warrant either dangerous or impossible, United States v. Santana, 427 U.S. 38, 42-43 (1976), and searches incident to arrest, Chimel v. California, 395 U.S. 752, 763 (1969). For a different formulation of these exceptions, see Texas v. Brown, $103 \mathrm{~S}$. Ct. 1535, 1539 (1983) (plurality opinion) (flexible, common-sense exceptions). While most types of cases require warrants, the few warrantless categories include large numbers of cases.

9. Walter v. United States, 447 U.S. 649 (1980) (warrantless viewing of film misdelivered to third party who gave film to police violates Fourth Amendment); Payton v. New York, 445 U.S. 573 (1980) (entry into home to make routine arrest without arrest warrant violates Fourth Amendment).

10. Compare T. Taylor, Two Studies in Constitutional INTERPRetation 29-35 (1969) (for Framers, searches could be reasonable and unwarranted; their concern was general warrants) with Amsterdam, Perspectives On The Fourth Amendment, 58 Mins. L. Rev. 349, 395-99 (1974) (reasonableness clause meant to expand warrant clause; warrant a minimum requirement of reasonableness). 
seizures as "per se unreasonable" unless they fall into one of the limited exceptions to the warrant requirement. ${ }^{11}$

In the seventeen years since Camara v. Municipal Court ${ }^{\mathbf{2}}$ was decided, the courts have begun to apply the Fourth Amendment to governmental activities outside criminal law enforcement. ${ }^{13}$ This extension of the Fourth Amendment results largely from the expansion of the administrative state and its capacity to regulate citizens' lives. ${ }^{14}$ The new legal doctrine has engendered doubts that the doctrines evolved in the past will be suited to the present range of problems. ${ }^{15}$

When the Supreme Court extended the Fourth Amendment to civil cases, it introduced a second methodology. ${ }^{16}$ The Court used a new balancing approach to measure the reasonableness of a search or seizure,

11. Mincey v. Arizona, 437 U.S. 385, 390 (1978) (citing Katz v. United States, 389 U.S. 347, 357 (1967)).

12. 387 U.S. 523 (1967).

13. Until 1967, the Fourth Amendment served mostly as a constraint on criminal law enforcement, leaving civil law enforcement untouched. See Frank v. Maryland, 359 U.S. 360, 367-72 (1959) (Fourth Amendment should not apply to activities of health inspector, because they are indispensable and not overly inconvenient); Murray's Lessee v. Hoboken Land \& Improvement Co., 59 U.S. (18 How.) 272, 285 (1855) (Fourth Amendment "has no reference to civil proceedings for the recovery of debts"). But in Camara v. Municipal Court, 387 U.S. 523 (1967), and See v. City of Seattle, 387 U.S. 541 (1967), the Court reversed itself, holding that the Fourth Amendment would govern the activities of housing and fire inspectors as they searched public housing and places of business. The searchers in these cases had failed to obtain either a search warrant or the consent of the owners, thereby invalidating the prosecutions for refusal to allow entry.

Although the Amendment had attained some force outside the realm of criminal procedure, the opinions remained ambiguous about whether Fourth Amendment interests would receive precisely the same protection in the civil and criminal contexts. See $3 \mathrm{~W}$. LaFAve, Search and Seizure: A Treatise on THE Fourth AMENDMENT $\$ 10.1$, at 188-91 (1978) (noting this ambiguity in the Camara opinion).

14. Curiously, commentators from almost every period in American history have perceived the federal government to be expanding and threatening individual liberties. See Wood, The Scope of the Constitutional Immunity Against Searches and Seizures, 34 W. VA. L.Q. 1, 2 (1927) (despite fact that "paternal government can and must regulate the life of its citizens to an extent hitherto unknown," people insist on stronger Fourth Amendment protections than ever). Yet it is undeniable that government during this century has assumed its most far-reaching regulatory role to date. See gener-

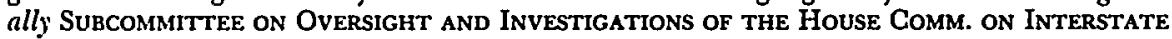
and Foreign Commerce, 94th Cong., 2d Sess., Federal Regulation and Regulatory ReFORM (Comm. Print 1976) (overview of activities of nine different agencies, followed by intricate reform proposals).

The government's participation is no longer exceptional in civil cases. See United States v. City of Philadelphia, 644 F.2d 187 (3d Cir. 1980), reh'g denied, 644 F.2d 206 (3d Cir. 1981); Director of the Admin. Office of the U.S. Courts, ANnuAl Report 98 (1982) (number of civil cases filed by United States in federal court up $199.4 \%$ since 1977); Fiss, The Supreme Court, 1978 Term-Foreutord: The Forns of Justice, 93 HARv. L. REv. 1, 20 (1979).

15. For examples of the variety of civil Fourth Amendment claims, see infra notes $22 \& 25$. Skepticism of this type often attaches to legal principles when they are extended to cover more diverse situations. It arose, for example, when an expansive reading of the Fourteenth Amendment's equal protection clause required strict scrutiny for non-racial classifications. See L. TRIBE, AMERICAN ConSTITUTIONAL. LAW $\$ \$ 16-22$ to $16-32$, at 1052-97 (1978).

16. Camara v. Municipal Court, 387 U.S. 523, 536-37 (1967) ("Unfortunately, there can be no ready test for determining reasonableness other than by balancing the need to search against the invasion which the search entails."). The balancing methodology quickly became independent from any concern over warrants or probable cause. See Bell v. Wolfish, 441 U.S. 520 (1979). 
weighing the government's need to conduct the search against the extent to which the search intruded into personal privacy. After weighing both elements, a court could conclude that the search or seizure required a justification of probable cause, one lower than probable cause, or no justification at all. 17

This approach may sound like a disguised version of the probable cause approach, for in a broad sense, every Fourth Amendment case balances the needs of law enforcement against individual rights of privacy or liberty. ${ }^{18}$ But in a case decided by balancing, a court reconsiders the proper balance between law enforcement and privacy interests in each case ${ }^{19}$ rather than relying on some prescribed balance. ${ }^{20}$ The probable cause methodology, by contrast, strikes a balance once at the outset, so that in individual cases a more limited set of factors bears on the outcome. To find probable cause, courts consider only the expertise of an officer (or veracity of an informant) and the amount and quality of information about the target available to the police before the search or seizure. ${ }^{\mathbf{2 1}}$

17. Villamonte-Marquez v. United States, 103 S. Ct. 2573 (1983) (no suspicion at all necessary to board vessel); United States v. Brignoni-Ponce, 422 U.S. 873 (1975) (officers need specific articulable facts). While it is logically possible to require probable cause or some higher level of justification in a balancing case, the Court has never done this in cases where the balance is set anew. See infra $\mathrm{p}$. 1142 .

18. Michigan v. Summers, 452 U.S. 692, 706 (1981) (Stewart, J., dissenting) (Terry was isolated exception to "general rule that the Fourth Amendment itself has already performed constitutional balance between police objectives and personal privacy"); Brinegar v. United States, 338 U.S. 160, 176 (1949) ("The rule of probable cause is a practical, nontechnical conception affording the best compromise that has been found for accommodating these often opposing interests.").

19. Some have described the balancing approach much differently. Under the alternative view, balancing does not reconsider all factors in every case, but proceeds on a "categorical" basis, striking a balance between the relevant factors for each type of case. See Dunaway v. New York, 442 U.S. 200, 219-20 (1979) (White, J., concurring); 1 W. Ringel, SEarches and SeIzures, ARrests and CoNFEssions 1-6 (2d ed. 1982).

Happily, it is true that some forms of balancing could be squared with the ideal of prospective rules. When a court balances many considerations and announces a standard that will guide future decisions for a large category of cases, it has made a rule. As the size of the category decreases, so does the rule-like quality of the decision. Several decisions under the balancing rubric, however, give reason to suspect that the categories employed in those cases are indeed narrow ones. United States v. Place, 103 S. Ct. 2637 (1983) (many investigative stops in airports require no consent); Florida v. Royer, 103 S. Ct. 1319 (1983) (plurality opinion) (consent tainted by impermissible investigative stop in airport); United States v. Mendenhall, 446 U.S. 544 (1980) (consent to search after investigative stop in airport held voluntary); see also Michigan v. Summers, 452 U.S. 692 (1981) (detention of person at scene of a search for questioning, no probable cause); Dunaway v. New York, 442 U.S. 200 (1979) (detention of persons for questioning at police station requires probable cause).

Cases fall into the same category when they involve roughly the same "governmental need" and "intrusiveness." But because of the vagueness of those two ideas, especially as used outside the early stop-and-frisk cases, the need in one case could always be cast differently from the need in the next case. Where categories remain undefined, there is always room for one more.

20. The probable cause approach assumes that probable cause resolves conflicting interests for all cases. Dunaway v. New York, 442 U.S. 200 (1979); see supra note 18.

21. See Whitely v. Warden, 401 U.S. 560 (1971); 1 W. LAFAVE, supra note 13 , \& 3.2, at 461-76; 1 W. RiNGel, supra note 19 , at 4-16 to $4-36$. While it is conceivable that a probable cause standard might take into account the fact that a warrant was sought, United States v. Ventresca, 380 U.S. 102, 106 (1965), or that a search will be unusually intrusive, Gooding v. United States, 416 U.S. 430 
The balancing approach has become a fixture in the civil applications of the Fourth Amendment. ${ }^{22}$ Commentators have passed over the significance of the relationship between that methodology and the civil applications, ${ }^{23}$ perhaps because the Court has not singled out the civil nature of

(1974) (Marshall, J., concurring), these factors influence only a few marginal cases, if any.

Illinois v. Gates, 103 S. Ct. 2317 (1983), casts a shadow over some of this. The opinion might be read to endorse an eclectic and unreviewable effort by the magistrate to find probable cause in the "totality of the circumstances." Id. at 2332 (magistrate considers "all the circumstances set forth in the affidavit . . . including the 'veracity' and 'basis of knowledge' of persons supplying hearsay information"). If the opinion does mean that any type of information could produce probable cause and that it is not at all subject to rules, then this Note understates the extent to which the Court has rejected rules under the Fourth Amendment. Interestingly, the Gates opinion relies prominently on a border search balancing case (United States v. Cortez, 449 U.S. 411 (1981)), and a stop-and-frisk balancing case (Adams v. Williams, 407 U.S. 143 (1972)). 103 S. Ct. at 2328-29.

The Gales opinion need not be read so bleakly. The Court seemed most concerned to refute the idea that the two prongs of the Aguilar-Spinelli probable cause test were separate and independent requirements of probable cause. Id. at 2327-28 \& n.5, 1229-30 \& n.9. Perhaps the decision only changed the interaction between variables without adding any new ones. Id. at 2332 (Court refers to the relevance of circumstances "in the affidavit"). The affidavit requirement might foreclose any consideration of the seriousness of the crime or other similar factors.

In balancing, a nearly unlimited number of factors influence the outcome of the case. See Bell v. Wolfish, 441 U.S. 520,559 (1979). Of all the possible factors, the nature of the governmental objective can make the most-if not all-the difference in what the Fourth Amendment requires. See United States v. Brignoni-Ponce, 422 U.S. 873, 878-79 (1975).

22. The Court has frankly acknowledged its use of balancing in some types of cases, see Bell v. Wolfish, 441 U.S. 520 (1979). In administrative search cases, the Court's analysis has tended to focus on the questions central to the balancing methodology. Donovan v. Dewey, 452 U.S. 594, 600, 604 (1981) (warrantless searches "necessary to further a regulatory scheme"; intrusiveness of searches limited by "predictable and guided federal presence"); Marshall y. Barlow's, Inc., 436 U.S. 307, 320-21 (1978) ("reasonable legislative or administrative standards . . . are satisfied"); United States v. Biswell, 406 U.S. 311, 315-16 (1972) (no individual suspicion necessary for searches of firearms dealers, "carefully limited in time, place, and scope").

The Court has also used balancing in several cases containing elements of both a civil and a criminal nature, such as routine traffic regulation or border searches. See United States v. VillamonteMarquez, 103 S. Ct. 2573 (1983) (Coast Guard search); Texas v. Brown, 103 S. Ct. 1535, 1541 (1983) (arrest based on information about objects in plain view obtained after car stopped for routine safety inspection); Delaware v. Prouse, 440 U.S. 648, 653-55 (1979) (random stop to check driver's license); United States v. Ramsey, 431 U.S. 606, 618-19 \& nn.13-14 (1977) (search of international mail entering country); South Dakota v. Opperman, 428 U.S. 364, 369-71 (1976) (inventory searches of impounded vehicles); Cady v. Dombrowski, 413 U.S. 433, 447-48 (1973) (search for firearm in trunk of impounded vehicle); Almeida-Sanchez v. United States, 413 U.S. 266 (1973) (roving border patrol); United States v. Van Leeuwen, 397 U.S. 249, 252 (1970) (delayed delivery of suspicious package mailed from border town). Where the Court has chosen the balancing approach, however, it has de-emphasized the criminal aspects of the case. Opperman, 428 U.S. at 368 \& n.5 ("Most of this contact is distinctly non-criminal in nature."); Cady, 413 U.S. at 442 (emphasizing traffic control aspect of police activity). The border patrols enforce criminal laws against importing illegal aliens, but their efforts also result in prevented entries without criminal penalties. See United States v. Villamonte-Marquez, 103 S. Ct. 2573, 2581 (1983) (emphasizing routine regulatory character of foreign vessel documentation laws); United States v. Ortiz, 422 U.S. 891, 900-14 (1975) (Burger, C.J., concurring); Almeida-Sanchez v. United States, 413 U.S. 266, 278 (1973) (Powell, J., concurring) (roving border patrols "are undertaken primarily for administrative rather than prosecutorial purposes"). The border searches involving drug couriers, however, are cast unambiguously as criminal cases. See Reid v. Georgia, 448 U.S. 438 (1980). This exception is of recent vintage, and may be seen as part of the general trend toward equating balancing in the civil and criminal areas. This Note uses the "civil" designation to include all of these cases outside the traditional core of criminal law enforcement.

23. Sep Greenberg, The Balance of Interests Theory and the Fourth Amendment: A Selective Analysis of Supreme Court Action Since Camara and See, 61 Cal.r. L. Rev. 1011, 1014-16 (1973) 
cases to explain its resort to balancing. ${ }^{24}$ In some civil cases, moreover, the Court does not even appear to acknowledge its use of the balancing methodology. ${ }^{25}$ Even in some of the cases where the Court admits to balancing, no explanation appears for that choice of methodology. ${ }^{26}$ There are some hints that the unfamiliarity of interpreting the Fourth Amendment in a civil context prompts the move to balancing; ${ }^{27}$ in the Court's eyes, the new methodology applies only to cases differing radically from the Fourth Amendment criminal precedents. In a few of the civil cases the Court has pointed to factors such as low intrusiveness or high public need as justifications for balancing. ${ }^{28}$ But beyond those references, the choice of balancing in the civil area has gone unexamined.

Only months after the first use of balancing in a civil case, the Court used the test in Terry $v$. Ohio ${ }^{29}$ to evaluate a limited physical search of a suspect by a criminal law enforcement officer. ${ }^{30}$ As with civil cases, the

(Court should use balancing more explicitly and consistently, as it is well suited to problems in both civil and criminal areas); Note, Decriminalization: $A$ New Consideration for the Fourth Amendment Balance, 31 ME. L. Rev. 375, 380-81 (1980) (searches in all contexts are a "product of the same balancing of societal and individual interests"); see also $3 \mathrm{~W}$. LAFAVE, supra note 13, § 9.1, at 13-15 (equating balancing tests under Terry and Camara). This Note disagrees with Professor LaFave (always a reckless thing to do) by arguing that Terry balancing differs from Camara balancing; Terry balancing is always preceded and framed by a more complete debate over methodology.

24. One must carefully distinguish between the cases where the Court does in fact balance and the cases where it says it is going to balance. The Court has never fastened upon the civil nature of a case per se, but it has singled out factors that might be thought to characterize civil cases as a group.

25. See Nixon v. Administrator of Gen. Servs., 433 U.S. 425, 460-62 (1977) (statutory powers of government archivists to sort through personal papers of former President Nixon to determine which of them had historical significance reasonable because, on balance, the public interest was more important than the personal interests at stake); see also Michigan v. Tyler, 436 U.S. 499, 506 \& n.5 (1978) (fire and arson investigation); Whalen v. Roe, 429 U.S. 589, 598-604 (1977) (prescription drug registration program); United States v. Miller, 425 U.S. 435, 445-46 (1976) (governmental access to depositors' records governed by subpoena standards, not search warrant standards); Wyman v. James, 400 U.S. 309, 318-24 (1971) (unannounced visit by welfare worker not an unreasonable search); cf. United States v. Janis, 428 U.S. 433, 453-54 (1976) (holding, after balancing benefits and costs, that the exclusionary rule is not applicable to civil tax proceedings when evidence obtained by state agents).

26. See, e.g., Bell v. Wolfish, 441 U.S. 520, 559 (1979); Michigan v. Tyler, 436 U.S. 499, 506 (1978); Cady v. Dombrowski, 413 U.S. 433, 448 (1973) ("[V]ery little that we might say here can usefully refine the language of the Amendment itself . . . .").

27. See Almeida-Sanchez v. United States, 413 U.S. 266, 278 (1973) (Powell, J., concurring); Wyman v. James, 400 U.S. 309, 320, 323-24 (1971) (home visits constitute an established routine; requiring probable cause warrant would be an abrupt departure from current practice); Camara v. Municipal Court, 387 U.S. 523, 539 (1967) (long-time acceptance of inspections makes continued searches on less than probable cause reasonable).

28. See, e.g., Delaware v. Prouse, 440 U.S. 648, 658 (1979); United States v. Brignoni-Ponce, 422 U.S. 873,880 (1975).

29. 392 U.S. 1 (1968). Terry was argued before the Court on December 12, 1967, six months after the Camara decision.

30. Because of the great need to allow police officers to protect themselves and the brief duration of the search, neither probable cause nor a warrant were necessary to make the search reasonable. $I d$. at 30-31. In a companion case, Sibron v. New York, 392 U.S. 40 (1968), the Court overturned a conviction because the officer conducting the frisk had been seeking narcotics and not a deadly weapon. 
Court invoked balancing in this area because it had never before addressed the constitutionality of this type of activity. ${ }^{31}$

But despite almost simultaneous beginnings in the civil and criminal cases, balancing flourished in the civil cases alone. Balancing remained an exceptional methodology in criminal cases; courts applied it in only the few cases most closely resembling Terry, known as the "stop-and-frisk" cases. ${ }^{32}$ In contrast to its silence in the civil area, the Court offered some assurance in the criminal cases that the dangers of balancing could be controlled. ${ }^{33}$ It tried to fashion some meaningful limits to the concepts of high public need and low intrusiveness. ${ }^{34}$ Even within these limits, balancing was received critically by observers of and dissenters on the Court, although they had acquiesced in comparable balancing cases in the civil area. $^{35}$

31. Terry, 392 U.S. at 20 (stop-and-frisk not subject to usual Fourth Amendment rules because it is part of "an entire rubric of police conduct . . . which historically has not been, and as a practical matter could not be, subjected to the warrant procedure") (footnote omitted).

32. Sep Michigan v. Summers, 452 U.S. 692 (1981) (person detained at site of search); Reid v. Georgia, 448 U.S. 438 (1980) (per curiam) (drug courier profile did not provide reasonable suspicion necessary for stop); Dunaway v. New York, 442 U.S. 200 (1979) (investigative detention for questioning requires probable cause); Ybarra v. Illinois, 444 U.S. 85 (1979) (search of person at site of search warrant disallowed); Brown v. Texas, 443 U.S. 47 (1979) (stop-and-frisk unreasonable when conducted without specific objective basis for suspecting individual of criminal activity); Pennsylvania v. Mimms, 434 U.S. 106 (1977) (per curiam) (frisk of person stopped in a car for traffic violations); Adams v. Williams, 407 U.S. 143 (1972) (limited search for weapons on the basis of an anonymous tip); Davis v. Mississippi, 394 U.S. 721 (1969) (investigative detention for fingerprinting).

33. See Dunaway v. New York, 442 U.S. 200, 213 (1979); Ybarra v. Illinois, 444 U.S. 85, 93-94 (1979); Brown v. Texas, 443 U.S. 47, 51 (1979). But cf. Pennsylvania v. Mimms, 434 U.S. 106, 114 (1977) (Marshall, J., dissenting) (suggesting that Court had abandoned all possible limits on balancing).

34. The Court responded to the dangers of balancing primarily with the claim that the minimal amount of intrusion involved was significantly lower than that involved in a traditional search or arrest. Sep Mimms, 434 U.S. at 111 (the intrusion "hardly rises to a "petty indignity" ); Adams, 407 U.S. at 148 ("constituted a limited intrusion designed to insure [the officer's] safety"). Intrusiveness was measured partly as a function of time. Brown v. Texas, 443 U.S. 47, 50 (1979) (time enough to identify oneself); Pennsylvania v. Mimms, 434 U.S. 106, 111 (1977) (per curiam) (noting that there was no extra detention time); Adams v. Williams, 407 U.S. 143 (1972) (time enough to disarm suspect). Moreover, low intrusiveness was a condition necessary but not sufficient for balancing. Ybarra v. Illinois, 444 U.S. 85, 92-94 (1979) (search of limited intrusiveness not allowed; no reason to suspect that officers were in danger).

Concern for personal safety of police officers and citizens made the public need in the stop-and-frisk cases unusually urgent. In every stop-and-frisk case approving the police action involved (before $M$ ichigan 21 . Summers), the target had a weapon and the Court stressed that fact. Mimms, 434 U.S. at 111; Adams, 407 U.S. at 147-48 \& n.3; Terry, 392 U.S. at 23-24. One might have concluded from this that a valid stop could be employed only to prevent violent acts. But cf. Davis v. Mississippi, 394 U.S. 721, 727-28 (1969) (police might get a warrant to fingerprint without probable cause). The stop-andfrisk cases might also be read to allow prevention of future crime only, rather than investigation of past crime. LaFave, "Street Encounters" and the Constitution: Terry, Sibron, Peters and Bejond, 67 MiCH. L. REV. 39, 63-67 (1968).

35. See Yackle, The Burger Court and the Fourth Amendment, 26 U. KAN. L. REv. 437 (1978); Note, Considering the Two-Tier Model of the Fourth Amendment, 31 AM. U.L. REv. 85, 112-22 (1981) (describing the abuse of the "middle level" searches such as the one in Terry). Compare United States v. Place, 103 S. Ct. 2637 (1983) (Brennan, J., concurring) (surveying the risks of balancing) and Terry v. Ohio, 392 U.S. 1, 39 (1968) (Douglas, J., dissenting) ("hydraulic pressures" to water 


\section{B. The New Acceptability of Balancing}

Balancing has of late become more acceptable in criminal cases. In a series of cases last Term ${ }^{36}$ including Michigan $v$. Long ${ }^{37}$ United States $v$. Place, ${ }^{38}$ and Florida v. Royer, ${ }^{38}$ the Court dropped the limitations on balancing that had made it the exception rather than the rule in criminal cases.

For the first time, the Court did not try to demonstrate the radical differences between the specific police activity involved in the case and other police activities generally subject to the Fourth Amendment. ${ }^{40}$ Where the Court had earlier used the balancing technique in criminal cases involving search or seizure of a person, it now used the technique to evaluate searches of areas ${ }^{41}$ and seizures of possessions. ${ }^{42}$ What was once thought the distinguishing justification for criminal balancing, concern for the immediate personal safety of police officers and citizens, was no longer necessary. A more general interest in law enforcement could now suffice. ${ }^{43}$

down constitutional rights and give police upper hand) wilh Marshall v. Barlow's, Inc., 436 U.S. 307, 325-26 (1978) (Stevens, J., dissenting) (does not question propriety of searches without individualized suspicion).

36. Michigan v. Summers, 452 U.S. 692, 702 (1981), and Reid v. Georgia, 448 U.S. 438 (1980) (per curiam), actually began this transition by allowing balancing in the absence of physical danger to police officers. Both Summers and Reid, however, dealt with the power to stop, not the power to frisk. A stop is less intrusive; thus, Michigan v. Long, 103 S. Ct. 3469 (1983), is the most troublesome of the new cases.

37. 103 S. Ct. 3469 (1983) (using balancing to approve a "protective search" of an automobile near a criminal suspect).

38. 103 S. Ct. 2637 (1983) (using balancing to approve some limited detentions of persons and luggage without probable cause, even while disallowing the 90-minute detention in question).

39. 103 S. Ct. 1319 (1983) (plurality opinion) (holding that seizure of person and luggage in airport was overly intrusive, but recognizing drug enforcement as a rationale for Terry-type stop). Two other recent cases reinforce the trends discussed here. United States v. Villamonte-Marquez, 103 S. Ct. 2573 (1983) (suspicionless boarding of vessel by Coast Guard), a classic non-criminal case, confirms two relevant propositions: It is difficult under balancing to group cases into "categories," sep supra note 19, and the concept of public need is limitless. Texas v. Brown, $103 \mathrm{~S}$. Ct. 1535, 1541 (1983), although holding only that a search based on information about objects within plain view of the officer was proper, appeared to reach that result by balancing, despite the fact that no special need or low intrusiveness was present.

40. Indeed, the entire thrust of the Place opinion was to suggest the continuity of most law enforcement techniques, and the similarity that most bore to the encounter in Terry. In response to the claims that there can be no "limited" seizure of property analogous to the limited search in Terry, the Court argued that many factors could reduce the intrusiveness of a seizure. Place, $103 \mathrm{~S}$. Ct. at 2643-44. Only dog sniffs seemed completely set apart from other law enforcement techniques.

41. Michigan v. Long, $103 \mathrm{~S}$. Ct. at $3482 \mathrm{n} .16$. Area searches could often take longer and expose more personal items because, unlike a pat-down of outer clothing, area searches usually cannot rely on the sense of touch alone.

42. United States v. Place, 103 S. Ct. at 2643. The opinion in Florida $\%$. Royer, meanwhile, does not specify whether the seizure of luggage would have been permissible if Royer himself had not been detained, but the Court's speculation about the dog sniff suggests that it would. $103 \mathrm{~S}$. Ct. at 1327-29. Seizure of possessions is usually based on some purpose other than protecting safety (except for the case of a hidden bomb or the like).

43. United States v. Place, 103 S. Ct. at 2643; Michigan v. Long, 103 S. Ct. at $3480 \mathrm{n} .14$ (search allowed in order to prevent suspect from hindering "legitimate police activity"). The Court in Long protested that officer safety motivated its decision. Id. But the Long decision gives police the rare 
Perhaps most tellingly, the Court became evasive about the limited nature of the intrusion, ${ }^{44}$ which it had always stressed in earlier criminal balancing. In each of these questions, the Court drew guidance from civil cases, starting a crossover that could have serious ramifications. ${ }^{45}$ The balancing approach is thus being assimilated, often without comment, into Fourth Amendment criminal jurisprudence.

\section{The Demise of the Givil-Criminal Distinction}

Abandoning the civil-criminal distinction was not the source of the Court's methodological problems. The distinction was always an unstable way to determine which methodology should apply, because both reasons advanced to explain when the balancing method should apply ${ }^{46}$-low intrusiveness and high public need-fail to justify the favored status of balancing in the civil area. An examination of both reasons reveals that they expand across the civil-criminal line and make the division irrelevant; there is no harm in abandoning an irrelevancy.

\section{A. Low Intrusiveness}

The claim of "low intrusiveness" hypothesizes that balancing is harmless when an intrusion into privacy interests is limited in scope or duration. Since civil searches and seizures are often considered less intrusive than their criminal counterparts, ${ }^{47}$ it seems appropriate to relax the requirements of the Fourth Amendment in the less threatening civil area. ${ }^{48}$

opportunity of creating for themselves enough danger to justify a Terry search, by allowing the suspect to stand near the car door.

44. The opinion in Long mentioned no limits on the duration of a search, and only limited its scope to "those areas in which a weapon may be placed or hidden." 103 S. Ct. at 3480. Summers, Royer, and Place all denied that an investigative stop could last for only a moment.

45. While civil cases had been cited in criminal opinions as early as Pennsylvania v. Mimms, 434 U.S. 106, 109 (1977) (per curiam), the earlier cross-references only supported the proposition that balancing could be performed. Only in Florida v. Royer, 103 S. Ct. 1319, 1324 (1983), and Michigan v. Summers, 452 U.S. 692,700 (1981), did the Court use civil precedent more broadly to decide precisely when balancing should apply.

46. The reasons appear routinely in judicial opinions and the scholarly literature. Those who raise them do not contend that the reasons actually entail a civil-criminal boundary for balancing. But since balancing has represented the norm in civil cases and not in criminal ones, the factors that support balancing should also support a distinction between civil and criminal cases.

47. The claim is that civil searches target institutions or large groups more often than individuals, and that many of them take place regularly and even predictably. See Bacigal, Some Observations and Proposals on the Nature of the Fourth Amendment, 46 GEO. WASH. L. REv. 529, 565-73 (1978) (governmental power most frightening when aimed at individual and not group); Note, Administratite Agency Searches Since Marshall v. Barlow's, Inc.: Probable Cause Requirements for Nonroutine Administrative Searches, 70 Gro. L.J. 1183 (1982) (routine administrative searches do not resemble criminal searches or seizures in their physical and psychical intrusiveness because they are regular and widespread). Under this view, the activities of civil officers need not be perceived as genuine threats. See Wyman v. James, 400 U.S. 309, 323 (1971) ("The caseworker is not a sleuth but rather, we trust, is a friend to one in need.").

48. See Donovan v. Dewey, 452 U.S. 594, 598 n.6 (1981); Michigan v. Tyler, 436 U.S. 499, 504 
One important clarification of this justification should be noted: The "intrusiveness" of a search or seizure has nothing to do with its ultimate purpose. The same search might lead to criminal penalties, such as imprisonment, or to civil sanctions, such as fines. But because the Fourth Amendment protects privacy interests rather than the interest in avoiding punishment, the purpose is not relevant. ${ }^{48} \mathrm{~A}$ person may have a greater interest in hiding something from a criminal officer than in hiding it from a civil officer, but the added interest comes from a fear of prison, not from fear of a loss of privacy. ${ }^{50}$ Privacy dissolves at the moment of intrusion, no matter what follows. To commingle privacy interests with an interest in avoiding punishment is to protect the worst offenders the most carefully. ${ }^{\text {s1 }}$

Even within a properly limited definition of "intrusiveness," criminal law enforcement is not systematically more intrusive than civil law enforcement. While intrusiveness may differ slightly between the two areas, there is an overlap large enough to make a civil-criminal dividing line senseless. The designation "civil" might bring to mind images of a detached government official overseeing a private dispute, but whenever the Fourth Amendment becomes an issue in a civil case, the government has

n.4 (1978); Ingraham v. Wright, 430 U.S. 651, 673 n.42 (1977) (belittling Fourth Amendment issue because of the civil context, namely, a public school); South Dakota v. Opperman, 428 U.S. 364,370 n.5 (1976); Wyman v. James, 400 U.S. 309, 322-24 (1971); see also McManis \& McManis, Structuring Administratize Inspections: Is There Any Warrant for a Search Warrant?, 26 AM. U.L. REv. 942, 960-65 (1977) (lack of hostility in civil searches pivotal in Court's Fourth Amendment decisions); Note, Administratize Search Warrants, 58 Minn. L. Rev. 607, 622-31, 640-42 (1974) (more demanding warrant requirement should apply only to atypical, nonroutine civil search).

49. The Supreme Court has articulated the purpose of the Fourth Amendment in several ways. See Texas v. Brown, 103 S. Ct. 1535, 1546 (1983) (Stevens, J., concurring) ("The Amendment protects two different interests of the citizen-the interest in retaining possession of property and the interest in maintaining personal privacy. A seizure threatens the former, a search the latter."); Warden v. Hayden, 387 U.S. 294, 304 (1967) ("principal object of the Fourth Amendment is the protection of privacy rather than property"); Schmerber v. California, 384 U.S. 757, 767 (1966) ("The overriding function of the Fourth Amendment is to protect personal privacy and dignity against unwarranted intrusion by the State."). The protection of personal privacy seems to be the common element of the cases. Fourth Amendment rights belong to individuals even though protection of personal privacy benefits society at large. Rakas v. Illinois, 439 U.S. 128 (1978); see Doernberg, "The Right of the People": Reconciling Collective and Individual Interests Under the Fourth Amendment, 58 N.Y.U. L. REV. 259, 260 (1983).

50. Assuming that the consequences of an act become worse if the act is a criminal rather than a civil violation, but of. infra note 52, the target fears a search for evidence of the act partly out of concern for privacy and partly out of fear of reprisal, a fear that increases in the criminal law area. The injury to privacy arises from the fact that someone, anyone, has intruded without justification; only the interest in self-protection varies with the motive of the intruder.

The phrase "self-protection," describing the interest in avoiding punishment, originated in the Court's opinion in Frank v. Maryland, 359 U.S. 360, 365 (1959). The idea that criminal defendants had privacy rights protected by the Fourth Amendment while other defendants did not was refuted in Camara v. Municipal Court, 387 U.S. 523 (1967). See Barrett, Personal Rights, Property Rights, and the Fourth Amendment, 1960 Sup. Cr. Rev. 46, 70-74; Loewy, The Fourth Amendment as a Device for Protecting the Innocent, 81 Mrch. L. REv. 1229, 1229-31 (1983); Posner, Rethinking the Fourth Amendment, 1981 Sup. Cr. Rev. 49, 50-53.

51. Under this interpretation, Fourth Amendment protection declines for those charged with lesser offenses, because the less serious the offense, the less is the expected punishment. 
aimed all its investigative efforts at a single target, just as in the criminal area. Civil law enforcement officers may use the investigative techniques available to criminal officials ${ }^{\mathbf{5 2}}$ and civil searches often take targets by surprise, requiring a scope and duration of investigation rarely seen in criminal cases. ${ }^{53}$ Indeed, civil searches may become the more intrusive because of the amount and specificity of information that agents must gather in order to enforce some civil laws. ${ }^{54}$

The fact that civil searches often target large groups of people does not significantly reduce their intrusiveness. ${ }^{55}$ The widespread nature of civil intrusions might make them even more fearsome than isolated criminal searches, even if the individual violations are small. While the institutional character of civil targets-often thought to make civil searches less intrusive-may reduce the privacy interests at stake, complex privacy interests exist in institutional settings, as well. ${ }^{66}$ In sum, intrusiveness does not vary systematically between civil and criminal cases.

The similarity in intrusiveness for civil and criminal cases could have divergent implications. One possible lesson to be drawn is that cases of

52. In fact, even the consequences of civil and criminal violations might be more similar than appears at first glance. Civil contempt makes physical confinement into a civil punishment; criminal fines make the consequences of a criminal violation the same as those of a civil violation, especially when the latter entails punitive damages. Termination of governmental support payments may approach physical confinement in its coercive impact. See generally Reich, The New Property, 73 YaLE L.J. 733, 737-39, 746-51 (1964) (governmental power enhanced by largesse).

While popular images of imprisonment and fines remain radically different, some commentators contend that fines have modified institutional behavior at least as effectively as physical confinement of institutional officials, and have proposed them as an appropriate centerpiece for future compliance schemes, see Becker \& Stigler, Law Enforcement, Malfeasance, and Compensation of Enforcers, $3 \mathrm{~J}$. LeGal STUD. 1, 6-13 (1974); Kraakman, Corporate Liability Strategies and the Costs of Legal Controls, 93 YALE L.J. 857 (1984).

53. See G.M. Leasing Corp. v. United States, 429 U.S. 338 (1977) (seizure of automobiles and other personalty by the IRS); Abel v. United States, 362 U.S. 217 (1960) (unusually broad inventory search and immigration arrest); IRS, INTERNAL ReVENUE MANUAL $\S 4235.5$, at 610-16(14)0, 3(11)0-3(11)5 (1977) (special examination procedures for "in-depth" examinations); Reich, Midnight Welfare Searches and the Social Security Act, 72 YALE L.J. 1347 (1963).

54. Detailed and complex regulations increase both the discretion and the scope of the duties of the searching officer. See 29 C.F.R. $\$ \S 1903,1910$ (1983) (796 pages of inspection procedures, followed by 796 pages of safety and health standards); IRS, supra note 53 , at $\S 4232.9$, at $110-740$ (Techniques Handbook for investigating financial institutions); Schuck, The Curious Case of the Indicted Meat Inspectors, HarPeR's, Sept. 1972, at 80.

55. In fact, the presence of extra witnesses could make searches of groups even more embarrassing. See Delaware v. Prouse, 440 U.S. 648, 664 (1979) (Rehnquist, J., dissenting) ("The Court . . . elevates the adage 'misery loves company' to a novel role in Fourth Amendment jurisprudence."); Lankford v. Gelston, 364 F.2d 197, 201-05 (4th Cir. 1966) (en banc) (large-scale violations of Fourth Amendment most inexcusable and make injunction appropriate); see also Tushnet, Darkness on the Edge of Toun: The Contributions of John Hart Ely to Constitutional Theory, 89 YALE L.J. 1037, 1045-48 (1980) (large-scale violations worst possible case, yet allowable under Ely's theory of the Fourth Amendment).

56. The privacy interests in institutions may be complex and interrelated, and therefore easily missed. See Zurcher v. Stanford Daily, 436 U.S. 547 (1978); Bloom, The Law Office Search: An Emerging Problem and Some Suggested Solutions, 69 GEO. L.J. 1, 12-24 (1980); Case Note, Rush v. Obledo, 20 J. FaM. L. 555 (1982). 
low intrusiveness will emerge in both civil and criminal law enforcement: The least intrusive criminal cases would become balancing cases, and the most intrusive civil cases would change to probable cause.

Or the similarity might lead in another direction entirely. Until recently, the intrusiveness of a criminal search made no difference in determining the extent of protection which should be afforded. ${ }^{57}$ If varying degrees of intrusiveness do not require different methodologies within the criminal area, perhaps low intrusiveness should never make a difference. This claim calls balancing into question wherever it occurs, whether in civil cases alone or in low intrusiveness cases that are both civil and criminal. To the extent that the two reactions to intrusiveness represent different philosophies of the proper relation of an individual to the state, the traditional acceptance of the probable cause approach makes it seem the more well-considered of the two. ${ }^{.8}$

\section{B. High Public Need}

A second justification for balancing, "public need," argues that civil law enforcement activities would be intolerably burdened if officials were obliged to comply with the Fourth Amendment principles that have controlled the criminal area. Courts must temper the requirements of the Amendment to maintain an acceptable level of law enforcement. ${ }^{59}$

One need not stretch to find a response to this justification. Both the civil and criminal laws respond to urgent public needs, and it does not suffice to say, as some have, ${ }^{60}$ that the level of public need differs because

57. For example, in Ybarra v. Illinois, 444 U.S. 85 (1979), the grant of a warrant for search of a tavern did not legitimate even the briefest of individual searches of the customers in the tavern. More frequently, investigations of low intrusiveness in the criminal area are not considered to be searches at all. United States v. Place, 103 S. Ct. 2637, 2644 (1983) (dog sniffs); United States v. Knotts, 103 S. Ct. 1081 (1983) (beeper); see Peebles, The Uninvited Canine Nose and the Right to Privac: Some Thoughts on Katz and Dogs, 11 GA. L. REv. 75 (1976). Once the Amendment begins to operate, intrusiveness does not influence the analysis. See Dix, Means of Executing Searches and Seizures as Fourth Amendment Issues, 67 MinN. L. REv. 89, 136-39 (1982).

58. Tradition is no adequate reason to choose one methodology over the other, but it should at least give pause to proponents of balancing. For other reasons to distrust balancing, see infra $\mathrm{p}$. 1138-42.

59. According to this argument, worker safety, public health, border security, tax collection, and other indispensable functions of government would be burdened intolerably by the probable cause approach. Fourth Amendment protections should take effect only where they further privacy interests more than they inhibit important law enforcement. See, e.g., LaFave, Administratize Searches and the Fourth Amendment: The Camara and See Cases, 1967 Sup. CT. REv. 1, 12-20 (administrative probable cause standard less stringent than usual probable cause standard because necessary for "acceptable" level of enforcement); Note, Administrative Searches and the Fourth Amendment: An Altermative to the Warrant Requirement, 64 CoRNELI L. REv. 856, 860-63 (1979) (criminal probable cause warrants not tailored to all of society's needs in civil area).

60. See Greenberg, supra note 23, at 1018; Note, The Fourth Amendment and Administratit' Inspections, 16 Hous. L. Rev. 399, 448-51 (1979) (proposing separate civil and criminal Fourth Amendment standards, based on special public need in civil area). 
civil law enforcement requires searches and seizures on a broad scale, necessitating a more relaxed standard. The argument that the Amendment must be reinterpreted to accommodate enforcement techniques developed without thought to the Constitution permits legislators and administrators to redefine reasonableness at will. ${ }^{\text {B1 }}$

In addition, claims of great public need have generally carried little weight in the criminal area where one might expect the need to be even greater. ${ }^{62}$ Even varying needs within the criminal context (e.g., the greater urgency to catch a psychotic killer than a pickpocket) have never altered the level of justification required before the government may invade a citizen's privacy. ${ }^{63}$ As the Court explained in Dunaway v. New York, ${ }^{64}$ a "single, familiar standard" is needed to guide police officers who have limited time and legal expertise to reflect on the social and individual interests at stake in a search.

As with the intrusiveness rationale, the treatment of claims of public need in the criminal context is instructive. It demonstrates that the civilcriminal distinction may have served as a false boundary for balancing. ${ }^{65}$ When one recalls that balancing has completely overrun the civil area under the banner of public need, a more sobering lesson emerges. A consistent use of the public need rationale could lead to the dominance of balancing in all areas of law enforcement. The civil-criminal distinction is untenable, but no other principle appears available to restrain the balancing methodology.

61. Law enforcement, in other words, should work within bounds set by the Fourth Amendment, not vice versa. Cf. Calabresi \& Melamed, Property Rules, Liability Rules, and Inalienability: One View of the Cathedral, 85 HARv. L. REV. 1089 (1972) (allocation of property would change dramatically with small changes in "starting points"). A similar objection could be made to the government's ability to manipulate reasonable expectations of privacy. See Ashdown, The Fourth Amendment and the "Legitimale Expectation of Privacy," 34 VAND. L. REv. 1289, 1295-98, 1310-21 (1981).

62. Criminal law prevents violent actions on the part of citizens, a task which political philosophers have long recognized as the first duty of a government. T. HobBes, Leviathan 223-28 (C. Macpherson ed. 1968); see also Illinois v. Gates, 103 S. Ct. 2317, 2331 (1983) ("The most basic function of any government" is "to provide for the security of the individual and of his property," an end served by criminal law) (quoting Miranda v. Arizona, 384 U.S. 436, 539 (1966) (White, J., dissenting)).

63. See Bacigal, The Fourth Amendment in Flux: The Rise and Fall of Probable Cause, $1979 \mathrm{U}$. ILL. L.F. 763, 767-76. Some, however, have proposed that probable cause should vary with the level of public need involved. Barrett, supra note 50, at 63; Weinreb, Generalities of the Fourth Amendment, 42 U. CHI. L. REv. 47, 69-72 (1974).

64. 442 U.S. 200, 213-14 (1979).

65. Readers who still believe the civil-criminal distinction makes some difference for the Fourth Amendment can make good use of my failure. They can contain the balancing methodology within some minority of Fourth Amendment cases, even if that minority is likely to be too large. 


\section{The Shortcomings of Balancing}

The Court seems now to be moving away from separate civil and criminal methodologies toward a more widespread use of balancing. Although a change was due, the Court has not properly planned the direction of change. It has overlooked the limits and dangers of balancing, largely because it has neglected the dangers of the methodology in civil applications, thus making balancing more acceptable without making it better understood. This section will discuss some of these unexamined defects.

\section{A. No Minimum Protections of Privacy}

The Fourth Amendment was intended to give individuals unwavering protection against the intrusions of government, even when the government acted for a majority with a great collective need. The history of the enactment of the Bill of Rights confirms that those provisions were intended to guarantee certain individual liberties beyond the reach of the federal government, even though its powers were already limited. ${ }^{66}$ The interpretation of the Amendment over time has also stressed the need for minimum protections. The "mere evidence rule," ${ }^{67}$ for example, gave individuals absolute assurance that some types of materials would remain beyond the reach of government.

Probable cause also represents an absolute minimum-an unchanging requirement ${ }^{\mathbf{6 8}}$ that the government demonstrate the likelihood that it has chosen the correct target and scope for its search. This requirement obliges the government to make a certain amount of effort to justify its action. At a minimum, probable cause forestalls ill-founded and hasty intrusions. $^{6 \theta}$

The need for minimum protections of individual privacy is not merely historical. Its appeal in the present flows from a widely held conception of

66. N. Lasson, The History and Development of the Fourth AMEndment to the U.S. Constitutron, reprinted in 55 The Johns Hopkins UNIVERSITY STUdies in Historical and Political Science 88-105 (1937); 2 B. Schwartz, The Bill of Rights: A Documentary HisTORY 1012-42 (1971); G. WoOd, The Greation of the AMERiCan Republic 1776-1787, 536-43 (1969).

67. The mere evidence rule states that warrants could issue to search for only contraband or the fruits of crime, and not for "mere evidence." This was one form of irreducible minimum protection because the Court considered private papers to be mere evidence. Gouled v. United States, 255 U.S. 298, 310 (1921). The Court gave up on this approach in Andresen v. Maryland, 427 U.S. 463 (1976). See Gerstein, The Demise of Boyd: Self-Incrimination and Prizate Papers in the Burger Court, 27 UCLA L. Rev. 343, 373-82 (1980); Note, Formalism, Realism, and Constitutionally Protected Privacy Under the Fourth and Fifth Amendments, 90 HARv. L. REv. 945, 964-79 (1977) (positing "relativist" and "formalist" phases in Fourth Amendment history; formalist period protected individuals in absolute terms).

68. See supra notes 21,63 .

69. The standard reaches ends as well as means. Probable cause rules out some law enforcement objectives because they necessitate ill-founded searches or seizures. 
individual rights: To say that an individual has a legal right is to say that society will respect it, even when respecting it becomes inconvenient. ${ }^{70}$ In keeping with this ideal of individual rights, many constitutional provisions grant inviolable minimum protections, ${ }^{71}$ which puts them at odds with a philosophy of act utilitarianism. ${ }^{22}$ Balancing is the methodology of act utilitarianism; ${ }^{23}$ hence, the balancing test that operates in the Fourth Amendment does not suit many constitutional provisions.

Similarly, a Fourth Amendment jurisprudence that provides for minimum protections cannot ground itself in act utilitarianism or balancing. Under balancing, governmental need to search or seize could grow so high in relation to intrusiveness that no justification at all would be necessary

70. Sep generally R. Dworkin, Taking Rights Seriously 184-222 (1977) (setting out concept of individual rights that "trump" social utilities); Mashaw, "Rights" in the Federal Administrative State, 92 YALE L.J. (forthcoming) ("statist" ideal of rights, defined by collective need, conflicts with our dignitary values).

71. For example, the Fifth Amendment furthers a policy of fairness to individuals as well as preservation of the reliability of evidence. L. LEVy, THE ORIGINS OF THE FifTH AMENDMENT 331-32 (1968). The First Amendment protects even those speakers who create unrest or other social inconveniences. Terminiello v. Chicago, 337 U.S. 1, 5 (1949). This is done, in part, to promote the autonomy of individuals. Scanlon, $A$ Theory of Freedom of Expression, 1 PHIL. \& PuB. AFF. 204, 215-22 (1972). The due process clauses of the Fifth and Fourteenth Amendments unabashedly allow fairness toward individuals to override collective utility. Kadish, Methodology and Criteria in Due Process Adjudicalion-A Survey and Criticism, 66 YALE L.J. 319, 346-50 (1957). See generally E. Corwin, The "Higher Law" Background of American Constitutional Law 46-57, 72-89 (1955) (tracing influence of Coke and Locke on early constitutional law, legitimating principled resistance to state action).

72. Act utilitarianism is a form of moral philosophy that determines the morality of an act by weighing all of its consequences; the best actions are those that increase the aggregate pleasure or happiness of an entire society, and such a moral decision occurs before undertaking any new action. Spe H. Sidgwick, The Methods of Etrics (7th ed. 1907).

73. This results not just from the weighing of opposing interests, but also from the timing of the exercise. The Fourth Amendment balancing test operates in almost every new case: Once decided, a particular case need not be reconsidered, but most cases have distinctive variables calling for a new balance.

The difference between the balancing and probable cause methodologies parallels the differencè between act utilitarianism and rule utilitarianism. Rule utilitarianism, like probable cause, measures the consequences of different types of actions and lays out beforehand a set of rules designed to maximize collective pleasure or happiness. When faced with particular moral choices, then, one is guided by the established rule rather than by the injunction to maximize aggregate happiness. See generally' R. Brandt, Ethical Theory 380 (1959) (early effort to separate "act" and "rule" utilitarianism); R. Hare, Moral Thinking: Its Levels, Method and Point 25-64 (1982) (two levels of moral thinking, intuitive and critical, roughly corresponding to rule and act utilitarianism); Rawls, Turo Concepts of Rules, 64 PHIL. REv. 3 (1955) (utilitarianism more defensible under concept of rules that makes clear the distinction between justifying a practice and justifying a particular act falling under it).

This modified form of utilitarianism begins to answer the problems of balancing (and, by implication, of act utilitarianism) discussed infra pp. 1142-42. If prospectivity becomes the defining characteristic of probable cause, then it also escapes many of the dangers of subjectivity that led Ronald Bacigal to reject probable cause. Bacigal, supra note 63, at 804 . One may, however, question whether rule utilitarianism adequately responds to the need for minimum individual protections. Sep Sen, $P$ ersonal Utilities and Public Judgments: Or What's Wrong with Welfare Economics, 89 EcoN. J. 537 (1979); Williams, A Critique of Utilitarianism in J. SMART \& B. WILliams, UTILITARIANISM For AND Against 77, 118 (1973). To the extent this is true, a Fourth Amendment methodology should perhaps be based on a more deontological moral philosophy. 
for choosing one target over another. Great need might outweigh even a significant amount of intrusiveness, meaning that government neither has to justify nor significantly restrict its activities. The danger is compounded because balancing imposes no a priori restraints on the choice of governmental objectives, but attempts only to require a relatively restrained means to the chosen end. ${ }^{74}$ Society may choose objectives hopelessly incompatible with existing Fourth Amendment doctrine, making privacy so costly that it would never outweigh the new-found public need. The knowledge that policy need not respect privacy when it becomes too inconvenient will skew the choice of policies, favoring those that ineluctably violate privacy. Balancing provides no end to this cycle. Probable cause, on the other hand, makes Fourth Amendment doctrine more rule-oriented and more consistent with a philosophy that underlies many of our legal institutions. $^{75}$

\section{B. Undervaluing Privacy Interests}

Balancing tests conflict with the principle of minimum protections wherever they appear. But the balancing methodology runs into special problems with the Fourth Amendment because of the difficulty of measuring privacy. Courts may misestimate the privacy claim for a number of reasons. First, a privacy claim is highly subjective. A judge cannot actually know how different persons in different contexts perceive an invasion of privacy, ${ }^{76}$ yet it is something that he or she must know in order to arrive

74. See Florida v. Royer, 103 S. Ct. 1319, 1331 n.* (1983) (Brennan, J., concurring) (plurality opinion might be read to suggest that absence of less intrusive means can make an otherwise unreasonable search reasonable). Compare Delaware v. Prouse, 440 U.S. 648, 663 (1979) (Delaware may pursue its aims by less intrusive means) with United States v. Villamonte-Marquez, 103 S. Ct. 2573, 2579-80 (1983) (holding consistent with Prouse because no less intrusive method practicable).

75. Even the simple commitment to procedural regularity seems to carry with it a requirement of announcing specific and accessible rules on a prospective basis. See generally L. FULLER, THE MoRALITY OF LAW 46-91 (1964) (prospective rules part of "internal morality" of law). Such a commitment may underlie our ideal of a republican form of government. Note, The Rule of Law and the Stales: A New Interpretation of the Guarantep Clause, 93 YALE L.J. 561 (1984). While it is possible to argue that the rule of law favors a substantive ethical position favorable to individual rights (i.e., a non-utilitarian position), J. RAz, THE AuTHORITY OF LAw 210-89 (1979), it seems even more plausible that rule utilitarianism accommodates procedural regularity more easily than act utilitarianism.

76. See Note, Protecting Privacy Under the Fourth Amendinent, 91 Yale L.J. 313, 330-35 (1981) (summarizing social science data confirming incommensurability of different notions of privacy); $c f$. F. HAyeK, THE Constitution of LiBERTy 22-38 (1960) (personal freedom necessary for social progress because of inevitable ignorance of any one person regarding the knowledge held by others); Deutsch, Responsibility of a Corporation: An Altempt at Implementation, 20 VILL. L. REv. 938 (1975) (following Wittgenstein in grounding need for privacy and liberty on limits of epistemology and language); Rawls, Social Unity and Primary Goods, in Utrilitarianism and Beyond 159, 179-85 (A. Sen \& B. Williams eds. 1982) (preferring "justice as fairness" to utilitarianism because former, through theory of primary goods, allows for more than one concept of good and thereby avoids making ambitious psychological assumptions about all persons). This problem of likely judicial error has not received the same attention as the problem of likely field officer error, infra note 78 . 
at an "objective" value for privacy. ${ }^{77}$ Hence, every effort to place an objective value on privacy interests risks error.

The second source of error is the complexity of Fourth Amendment doctrine, for even if judicial accuracy is possible, courts' telling others how to be accurate might not be. The Fourth Amendment would become too manipulable for fair and predictable enforcement if officers had to distinguish between different levels of privacy, public need, intrusiveness, and different types of justifications. And this head-spinning variety of factors often would have to be processed quickly. Governmental agents could rarely be sure of considering every relevant variable. ${ }^{78}$

These problems could infect any methodology, and could just as easily cause overvaluation of privacy. But balancing risks these errors more often than the probable cause methodology, simply because a court using balancing constantly values and revalues privacy interests. ${ }^{79}$ This frequency becomes important in light of the fact that the structure of the balancing test inclines courts to hear the needs of law enforcement more clearly than the claims of privacy: Frequent chances for error systematically weaken privacy. This is true because, with so many varied circumstances that could mean the difference between one closely balanced case and another, balancing tends to reduce the precedential weight of each decision.

Focusing on individual cases inclines a court to weigh law enforcement needs more heavily because the adversary process in the Fourth Amendment context produces specific fact situations least favorable to individuals. Reliance on the exclusionary rule screens out most of the plaintiffs who could make privacy claims in court other than those with dirty hands. ${ }^{80}$ Because the effectiveness of law enforcement is more susceptible to empirical proof than the extent of privacy concerns, the adversarial process highlights the former. ${ }^{81}$ In addition, Fourth Amendment cases often

77. See W. Prosser, Handbook of the Law of Torts $\S 32$, at 149-66 (4th ed. 1971) (objective reasonableness standard an abstraction from many subjective standards).

78. Dunaway v. New York, 442 U.S. 200, 213-14 (1979); Amsterdam, supra note 10, at 393 (sliding scale Fourth Amendment would become impossible to administer, "one immense Rorschach blot"); Dworkin, Fact-Style Adjudication and the Fourth Amendment: The Limils of Lauyering, 48 IND. L. Rev. 329 (1972); LaFave, "Case-by-Case Adjudication" Versus "Standardized Procedures": The Robinson Dilemma, 1974 SuP. CT. REv. 127, 141.

79. See supra p. 1128. Frequent attempts do not form a base of experience as one would expect, because the appropriateness of the value placed on privacy rarely receives confirmation. Probable cause, by contrast, considers privacy only once, in the original formulation of the standard designed to account for even the most intrusive searches.

80. The innocent person would have no incentive to press charges, other than to obtain some damage award for the amount of privacy lost, a figure that may prove elusive. Kamisar, Does (Did) (Should) the Exclusionary Rule Rest on a "Principled Basis" Rather Than an "Empirical Proposition'?, 16 CReighton L. Rev. 565, 567-71 (1983); Comment, Presumed Damages for Fourth Amendment Violations, 129 U. PA. L. REV. 192 (1980).

81. Law enforcement agencies keep prodigious records on crime and other social evils. Spe FBI, 1981 Uniform Crime Reports 1-4 (summary of Uniform Crime Reporting Program). Such records often come to the attention of the Court. See United States v. Ortiz, 422 U.S. 891, 900 (1975) 
set an institutional plaintiff against an individual defendant, which may confer an advantage on the experienced institutional litigant. ${ }^{\mathbf{2 2}}$

This bias of the balancing test has consistently made itself felt, for wherever balancing outcomes have departed from probable cause outcomes, they have increased the discretion of law enforcement officials. Warrants have issued on a showing of less than probable cause. ${ }^{83}$ Warrantless searches have become more common and acceptable, ${ }^{84}$ and probable cause has not been required for all warrantless searches. ${ }^{85}$

\section{Allocating the Methodologies}

One response to these problems would be to stop the use of balancing altogether. At the very least, courts must keep the balancing test from overwhelming the entire jurisprudence of the Fourth Amendment. We must replace the civil-criminal distinction with something less manipulable than a standard relying on intrusiveness or public need. Those two rationales have failed to constrain balancing in the civil area. So the criteria for the use of balancing, along with some features of the methodology itself, must be adjusted to account for its dangers. The civil history of balancing can guide this adjustment.

At the outset, courts must recognize problems inherent in balancing. The civil cases employed the balancing test uncritically-almost without hesitation. ${ }^{86}$ To avoid this fundamental mistake, courts should carefully separate their choice of methodology from other Fourth Amendment issues in a case. ${ }^{87}$ Adding a methodological stage to every case ensures that

(app.).

82. Galantar, Why the "Haves" Come Out Ahead: Speculations on the Limits of Legal Change, 9 LAW \& Soc'y Rev. 95, 97-104 (1974).

83. Marshall v. Barlow's, Inc., 436 U.S. 307 (1978). Although "administrative probable cause" began as one type of probable cause, any relation between the two is purely fictional. Note, Area Search Warrants in Border Zones: Almeida-Sanchez and Camara, 84 YAlE L.J. 355, 370-71 (1974). A multi-tiered system of justifications, however, may be more manageable within the tradition of probable cause than under balancing. Probable cause is more closely associated with the ideal of prospectivity and more likely to avoid the problem of splintering.

84. It would be pointless to argue that warrantless searches would be permitted only under a balancing methodology. There have always been exceptions to the warrant requirement in the criminal cases, but there has been some effort to limit the categories. Civil searches are different: Administrative searches occupy their own exception to the warrant requirement, and others receive approval completely outside the categories of exceptions. Even where criminal searches have proceeded with only loose connections to any of the categories, they have done so by following the lead of civil cases. Bloom, Warrant Requirement-The Burger Court Approach, 53 U. CoLo. L. REv. 691 (1982).

85. This is true even of some full-scale searches. See, e.g., United States v. Villamonte-Marquez, 103 S. Ct. 2573 (1983) (stopping and boarding of vessel without suspicion); Bell v. Wolfish, 441 U.S. 520 (1979) (prison procedures, including room searches and body cavity searches, conducted without probable cause).

86. See supra notes $25 \& 26$.

87. The separation of the methodological choice is a familiar move, appearing both in antitrust law, see Arizona v. Maricopa County Medical Soc'y, 457 U.S. 332, 342-55 (1982) (describing the role of the per se rule and the rule of reason), and in equal protection analysis, San Antonio Indep. 
courts will at least recognize the difficulties inherent in the different methods of deciding a case.

The choice of balancing should be constrained as well as informed. The courts should require that objective criteria be met before invoking balancing, criteria that will foreclose its use in cases that accentuate its dangers. A vacuous generality such as "substantial law enforcement needs"88 will not at all limit the uses of balancing; inquiries into "intrusiveness" and "public need" have never prevented balancing in the civil area. ${ }^{89}$ If the probable cause methodology is to have any predictable role at all, courts must establish more specific preconditions.

The criteria should allow balancing only when necessary to protect values that indisputably outweigh the interest in privacy, because of the probability of underestimating it. ${ }^{90}$ Immediate physical danger to police officers or citizens meets this description. It is a standard with a past, and until recently it successfully checked balancing within the criminal area. Furthermore, it vindicates a value, the life of an identifiable person in the immediate present, ${ }^{91}$ with such clarity and force that it is entitled to override privacy.

Second, having invoked the balancing approach, courts must modify the methodology. Outcomes which permit the government to search or seize without having at least an "individualized" and "articulable" suspicion should be declared illegitimate. Only by keeping the required justification at least that high can the courts ensure a minimum of protection under a balancing approach..$^{22}$

The courts should also reshape the balancing test with an overarching goal in mind: to make it a more rule-oriented, categorical methodology. This type of balancing has been attempted, but it failed due to the temptation to splinter groups of cases. In the end, success might depend less on particular analytical devices than on a continuing awareness of the consequences of methodological choices. ${ }^{93}$

School Dist. v. Rodriguez, 411 U.S. 1, 16-17 (1973) (describing the two-tier test: rationality review in all cases except those involving suspect class or fundamental right, where strict scrutiny applies).

88. The phrase appeared in United States v. Place, 103 S. Ct. 2637, 2643 (1983) (citing Michigan v. Summers, 452 U.S. 692,699 (1981)).

89. See supra notes $32-34$.

90. Sep supra p. 1141; of. R. DworkIN, supra note 70, at $185-90$ (extraordinary amount of social utility necessary before violating a right).

91. Cf. G. Calabresi \& P. Bobbitr, Tragic Chorces 18-28 (1978) (noting changes in resource allocation when value of life becomes specific and identifiable).

92. It is certainly true that even a search or seizure not based on individualized suspicion could provide some protection against the arbitrary discretion of governmental officials, so that one possible target could not be singled out above the others by a searcher with a grudge. Donovan v. Dewey, 452 U.S. 594, 601 (1981); Brown v. Texas, 443 U.S. 47, 51 (1979). But without individualized suspicion, the government may mistreat one so long as it mistreats all. If that is a minimum protection, it is not a very significant one. Sep supra note 55 .

93. Sep supra note 19. As this Note has hinted throughout, the lack of careful deliberation about 
Such changes in the balancing methodology were never envisioned by courts that applied it in civil cases. Yet, because this methodology may no longer be restricted to the civil context alone, imposing such limitations on balancing may be the only way to control it. Balancing mocks history, since understanding its past only confirms our inability in the end to understand and manage it.

-Ronald F. Wright

methodologies no doubt contributes to the splintering of categories. 